\title{
VALUE OF URICOSURIC AGENTS AND IN PARTICULAR OF G.28 315 IN GOUT
}

\author{
BY \\ G. D. KERSLEY, E. R. COOK, AND D. C. J. TOVEY \\ From the Rheumatism Research Unit, Royal National Hospital for Rheumatic Diseases, Bath
}

The value of uricosuric agents in the reduction of tophi was shown by Gutman and Yü (1957) to be marked in 36 of 82 cases of tophaceous gout and definitely present in 67 . To be effective salicylates had to be used in large doses which were not then free from the risk of causing mental and haemorrhagic complications. Benemid (probenecid) produced rashes in 5 per cent. and severe gastritis in 8 per cent. of patients, and in 10 per cent. it increased the number of acute attacks during its early administration. Some pain in the loins or gravel occurred in 9 per cent. of cases, usually when some evidence of calculi had already been noted.

Phenylbutazone (Butazolidin) has only a minimal uricosuric effect in long-term therapeutic dosage, but has a strong antiphlogistic effect in gout. Following its administration, two main metabolites have been found in the urine, G.27 202 (which is antiphlogistic and causes salt retention) and G.28 231 (which is uricosuric) (Fig. 1, opposite). This suggested that modification of the butyl side-chain of phenylbutazone might alter the uric acid excretory potency. Working on this hypothesis, a substance G.25 671 was discovered; this increased the excretion of uric acid but was toxic in some 10 per cent. of cases. Its sulphoxy metabolite, however, was still more potent and less toxic and was designated G.28 315 (Burns, 1957). It is this substance which is the subject of this investigation.

G.28 315 is rapidly absorbed and has a half-life of 3 hours. It must therefore be administered not less frequently than four times a day to be effective. It has no effect on inulin clearance, but urate and P.A.S. clearance is inhibited, suggesting that it causes no change in glomerular filtration but reduces tubular transport of certain substances (Burns, Yü. Ritterband, Perel, Gutman , and Brodie, 1957).

It has been pointed out that uricosuric effect appears to vary as the acidity of the Butazolidin-like compound, phenylbutazone having a cp of $4 \cdot 5$, G.25 671 of 3.9 , and G.28 315 of 2.9. This suggests that yet another analogue, G.23 with a cp of $2 \cdot 2$, may also be of interest from this point of view.

Gutman and Yü (1957) found that, using G.25 671 , four out of 65 cases produced a rash and that in five there were gastric complications. In only two $\dot{\omega}$ out of thirty patients given G.28 $315(0 \cdot 4-0.6 \mathrm{~g}$. daily) was dyspepsia a serious symptom. No other $\mathscr{\sigma}$ toxic complications were found. With G.25 671 은 some antiphlogistic as well as uricosuric effect was noted.

Ogryzlo and Harrison (1957), on comparison of $\frac{\mathbb{D}}{\square}$ individual cases, suggested that Benemid $3 \mathrm{~g}$., aspirin 6 g., phenylbutazone 1 g., G.25 6711 g., and G.28 $315 \quad 0.5 \mathrm{~g}$. have approximately the same uricosuric effect. In eleven cases treated with 0.5 Ð G.28 315, there were no toxic complications.

It was decided to make a clinical appraisal G.28 315, its uricosuric action, its effect on the plasma uric acid, its possible toxicity, and on its optimal method of administration. A series of fifteen cases of gout (12 men and 3 women) were $\stackrel{\mathbb{Q}}{\varrho}$ hospitalized. Their renal function was examined $\overrightarrow{\vec{B}}$ and they were placed on a control period of estimation of urinary uric acid for 7 days, $1 \cdot 0 \mathrm{~g}$. Benemid for 3 days, and $1.5 \mathrm{~g}$. Benemid for 4 days. After this there was another control period of 7 days, followed by the administration of G.28 $315100 \mathrm{mg}$. four times daily for 7 days, and then $200 \mathrm{mg}$. four $\overline{0}$ times daily for a further week. The patients were then discharged from hospital on a dosage of $400 \mathrm{mg}$. 尺े daily and were seen at monthly intervals for clinical and biochemical check. It has been shown (Kersley, 옹 Mandel, and Bene, 1951) that colchicine has no effect on uric acid excretion, and therefore in all cases $1 \mathrm{mg}$. colchicine per day was administered for $\overline{\mathrm{N}}$ the whole period in order to avoid as much as $\mathrm{N}$ possible the complication of acute attacks. Where $\tilde{N}$ acute attacks, not controlled by the colchicine, appeared during the trial, phenylbutazone $600 \mathrm{mg}$. O daily was administered for 2 days only and this always proved effective.

During the trial a normal diet with plenty of fluids $\stackrel{\oplus}{\rightarrow}$ was given, excluding only foods of very high purine 0 


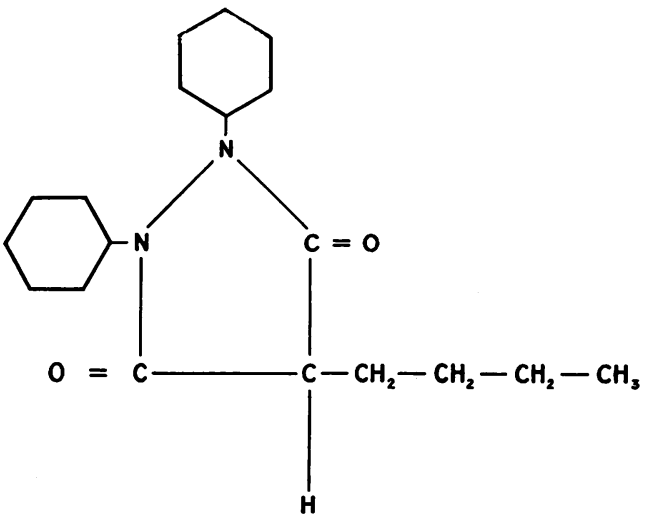

Phenylbutazone (Butazolidin)

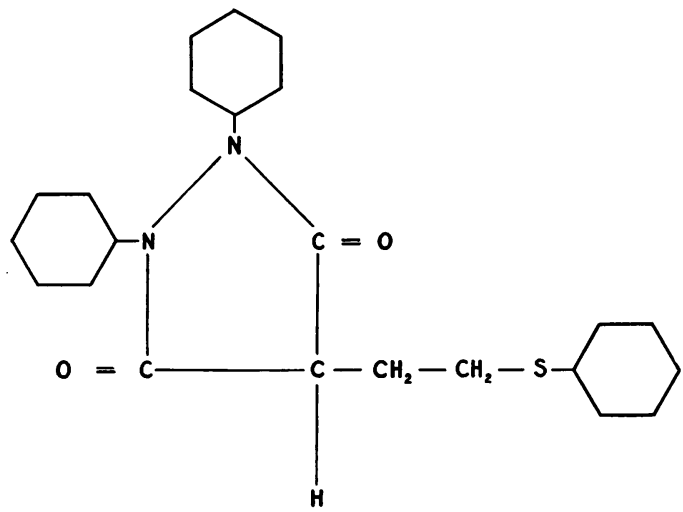

G.25 67I

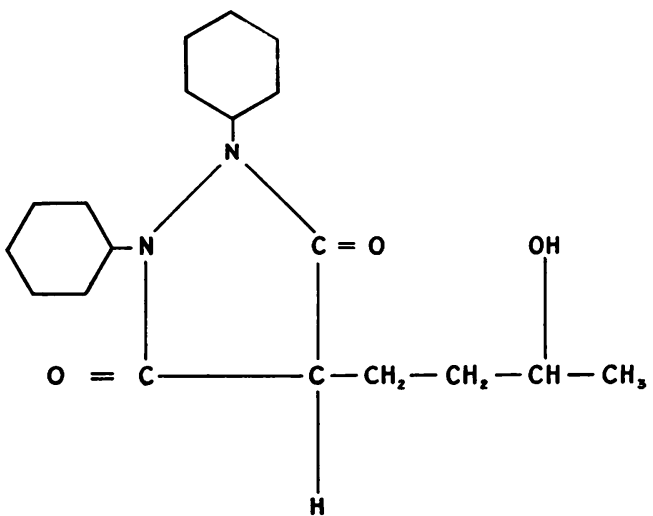

G.28 231

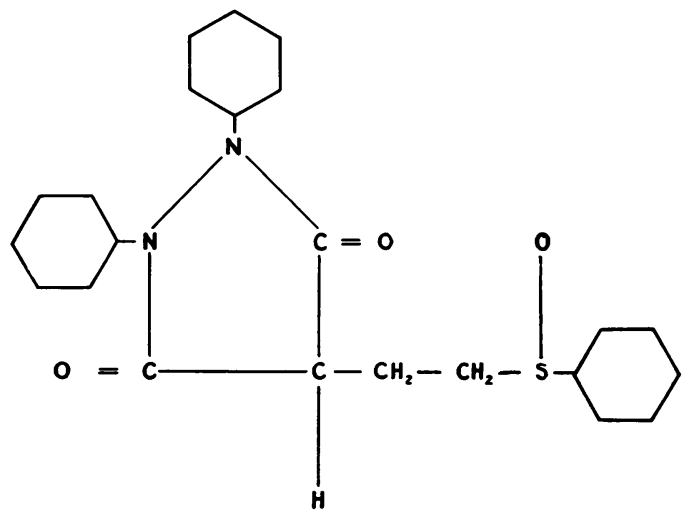

G.28 315

Fig. 1.-Chemical formulae.

content such as sweetbreads, fish roes, liver, kidney, etc. Urinary uric acid estimations were made by a modification of Folin's method (Bidmead, 1951).

In two cases in which $3 \cdot 5 \mathrm{~g}$. aspirin had previously been given-where some painful osteo-arthritis was a complication-this was replaced by pethidine temporarily for the control period. Two cases with slightly impaired renal function were similarly treated but are considered separately. White cell counts and complete urinary analyses were carried out periodically. In ten cases, after a period of continuous G.28 315 administration, the total weekly urinary excretion of uric acid was compared with that obtained by intermittent administration, i.e. for the first 3 days of each week. The effect of giving aspirin at the same time as G.28 315 was examined in nine cases in view of the antagonistic effect of aspirin and Benemid.

Table I (overleaf) shows the mean daily excretion of uric acid of thirteen patients taking a daily dose of $400 \mathrm{and} /$ or $800 \mathrm{mg}$. G.28 315 compared with the average levels in the control period. In seven cases a comparison is also made with the effect of 1 and $1 \cdot 5 \mathrm{~g}$. Benemid.

In all cases there was an increase in excretion of uric acid on giving $400 \mathrm{mg}$. of G.28 315, which was highly significant in ten and significant in the mean values for all thirteen cases. There was a further significant increase in excretion in three of five cases on raising the dosage to $800 \mathrm{mg}$., the average increase for the five also being significant. The administration of $400 \mathrm{mg}$. G.28 315 gave a greater increase in uric acid excretion than Benemid in five of the seven cases so tested, but the increase was significant in only two cases. Two patients showed little response to Benemid, but one responded to $400 \mathrm{mg}$. of G.28 315 and both to $800 \mathrm{mg}$. The average daily control excretion was $551 \mathrm{mg}$., which 
TABLE I

EFFECT OF BENEMID AND G.28 315 ON MEAN URIC ACID EXCRETION OF PATIENTS WITH GOUT

\begin{tabular}{|c|c|c|c|c|c|}
\hline \multirow[b]{3}{*}{$\begin{array}{c}\text { Patient } \\
\text { No. }\end{array}$} & \multirow[b]{3}{*}{ Sex } & \multicolumn{4}{|c|}{ Uric Acid Excretion (mg./24 hrs) } \\
\hline & & \multirow[b]{2}{*}{$\begin{array}{l}\text { Control } \\
5 \text { days }\end{array}$} & \multicolumn{3}{|c|}{ Treatment (g./24 hrs) } \\
\hline & & & $\begin{array}{c}\text { Benemid } \\
(1-1 \cdot 5) \\
7 \text { days }\end{array}$ & $\begin{array}{c}\text { G.28 } \\
(0.4) \\
7 \text { days }\end{array}$ & $\begin{array}{c}\text { G.28 } \\
(0 \cdot 8) \\
7 \text { days }\end{array}$ \\
\hline $\begin{array}{l}1 \\
2 \\
3 \\
4 \\
5 \\
6 \\
7\end{array}$ & $\begin{array}{l}\mathbf{F} \\
\mathbf{M} \\
\mathbf{M} \\
\mathbf{M} \\
\mathbf{M} \\
\mathbf{M} \\
\mathbf{M}\end{array}$ & $\begin{array}{l}549 \\
521 \\
506 \\
774 \\
722 \\
326 \\
673\end{array}$ & $\begin{array}{r}719 \\
653 \\
820 \\
1,081 \\
1,059 \\
554 \\
890\end{array}$ & $\begin{array}{r}688 \\
752 \\
869 \\
1,105 \\
1,050 \\
800 \\
1,138\end{array}$ & $\begin{array}{r}804 \\
815 \\
1,047 \\
1,291 \\
1,253\end{array}$ \\
\hline Mean & & 581 & 825 & 914 & 1,042 \\
\hline $\begin{array}{r}8 \\
9 \\
10 \\
11 \\
12 \\
13\end{array}$ & $\begin{array}{l}\mathbf{F} \\
\mathbf{M} \\
\mathbf{M} \\
\mathbf{M} \\
\mathbf{F} \\
\mathbf{M}\end{array}$ & $\begin{array}{l}435 \\
719 \\
504 \\
460 \\
504 \\
685\end{array}$ & & $\begin{array}{r}794 \\
1,372 \\
889 \\
840 \\
630 \\
756\end{array}$ & \\
\hline Mean & & 551 & & 880 & \\
\hline
\end{tabular}

on Benemid rose to $825 \mathrm{mg}$., and on G.28 315400 $\mathrm{mg}$. daily to $880 \mathrm{mg}$. and on G.28 $315800 \mathrm{mg}$. daily to $1,042 \mathrm{mg}$.

Table II shows that the effect on the serum uric acid levels was the opposite to the effect on the uricosuria. In all twelve cases the serum uric acid was markedly reduced and in the six which were also controlled against Benemid the fall was seen to be greater with G.28 315. The mean serum uric acid value of all cases was $7 \cdot 8 \mathrm{mg}$. per cent. in the control period, and dropped to $5.2 \mathrm{mg}$. per cent. on Benemid and to $4 \mathrm{mg}$. per cent. on G.28 315 .

It was thought that intermittent administration of G.28 315, as practised with cincophen, might be more economical and safer than continuous administration. The possibility of using G.28 315 in this way was suggested by the typical charts of greatest excretion during the first 3 days of administration (Fig. 2, opposite).
TABLE II

LEVELS OF SERUM URIC ACID (mg./100 ml. serum) DURING TREATMENT WITH BENEMID OR G.28 315

\begin{tabular}{|c|c|c|c|c|}
\hline \multirow{2}{*}{ Patient No. } & \multirow{2}{*}{ Sex } & \multirow{2}{*}{ Control } & \multicolumn{2}{|c|}{ Treatment } \\
\hline & & & Benemid & G.28 315 \\
\hline $\begin{array}{r}1 \\
2 \\
3 \\
4 \\
5 \\
6 \\
7 \\
8 \\
9 \\
10 \\
11 \\
12\end{array}$ & $\begin{array}{l}\mathbf{F} \\
\mathbf{M} \\
\mathbf{M} \\
\mathbf{M} \\
\mathbf{M} \\
\mathbf{M} \\
\mathbf{M} \\
\mathbf{F} \\
\mathbf{M} \\
\mathbf{M} \\
\mathbf{M} \\
\mathbf{F}\end{array}$ & $\begin{array}{r}8 \cdot 0 \\
6 \cdot 5 \\
9 \cdot 5 \\
6 \cdot 2 \\
10 \cdot 1 \\
-1 \cdot 0 \\
7 \cdot 6 \\
8 \cdot 3 \\
8 \cdot 8 \\
7 \cdot 7 \\
5 \cdot 1\end{array}$ & $\begin{array}{l}5 \cdot 1 \\
4 \cdot 6 \\
6 \cdot 3 \\
5 \cdot 3 \\
= \\
4 \cdot 6 \\
= \\
= \\
=\end{array}$ & $\begin{array}{l}2 \cdot 9 \\
3 \cdot 4 \\
4 \cdot 7 \\
4 \cdot 4 \\
4 \cdot 8 \\
-3 \cdot 8 \\
5 \cdot 7 \\
4 \cdot 2 \\
2 \cdot 8 \\
5 \cdot 0 \\
2 \cdot 3\end{array}$ \\
\hline \multicolumn{2}{|l|}{ Mean } & $7 \cdot 8$ & $5 \cdot 2$ & $4 \cdot 0$ \\
\hline
\end{tabular}

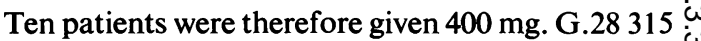
daily for a week, and then, after a 4-day rest, they N were given the same dose of G.28 315 for 3 days o followed by a further rest period of 4 days. The average uric acid excretion for the 2 weeks was $\vec{D}$ then compared. The average excretion for the $\mathbb{D}$ control week was $4,296 \mathrm{mg}$., for continuous treat- $\mathbb{\Phi}$ ment $6,571 \mathrm{mg}$., and for intermittent treatment $5,787 \mathrm{mg}$. The disadvantage of intermittent admin- $\frac{\mathbb{D}}{-}$ istration was illustrated by the serum uric act $\vec{\theta}$ levels; the average value after the use of G.28 3195 rose from 3.4 to $8.3 \mathrm{mg}$. per cent. at the end of tw 4-day rest period.

The patients treated with G.28 315 have now been on continuous treatment for from 3 to 8 months. Table III shows that there is no significant falling off in the effect of the drug on uric acid excretion or on 2 the serum uric acid levels. The mean excretion $\overline{\overrightarrow{0}}$ dropped only from 841 to $828 \mathrm{mg}$. (control $551 \mathrm{mg}$.) and the serum uric acid rose only from 4.5 to $4.8 \mathrm{mg}$. per cent. (control $7.8 \mathrm{mg}$. per cent.).

There have been no toxic symptoms of any kind so far in this group of cases. The white blood counts showed only a slight fall which was not

TABLE III

EFFECTS OF PROLONGED TREATMENT WITH G.28 315

\begin{tabular}{|c|c|c|c|c|c|}
\hline \multirow{2}{*}{ Patient No. } & \multicolumn{2}{|c|}{ After 1 Week's Treatment } & \multirow{2}{*}{$\begin{array}{c}\text { Duration of Treatment } \\
\text { (wks) }\end{array}$} & \multicolumn{2}{|c|}{ After Prolonged Treatment } \\
\hline & $\begin{array}{l}\text { Uric Acid Excretion } \\
\text { (mg./24 hrs) }\end{array}$ & $\begin{array}{l}\text { Serum Uric Acid } \\
\text { (mg./100 ml.) }\end{array}$ & & $\begin{array}{l}\text { Uric Acid Excretion } \\
\text { (mg./24 hrs) }\end{array}$ & $\begin{array}{l}\text { Serum Uric Acid } \\
\text { (mg./100 ml.) }\end{array}$ \\
\hline $\begin{array}{r}1 \\
2 \\
3 \\
4 \\
5 \\
11 \\
12 \\
13 \\
14\end{array}$ & $\begin{array}{r}744 \\
706 \\
780 \\
1,050 \\
1.013 \\
840 \\
- \\
\overline{757}\end{array}$ & $\begin{array}{l}3 \cdot 2 \\
3 \cdot 2 \\
5 \cdot 2 \\
4 \cdot 6 \\
5 \cdot 2 \\
5 \cdot 0 \\
2 \cdot 3 \\
7 \cdot 0 \\
5 \cdot 1\end{array}$ & $\begin{array}{r}12 \\
12 \\
8 \\
14 \\
6 \\
14 \\
4 \\
4 \\
10\end{array}$ & $\begin{array}{r}760 \\
759 \\
723 \\
965 \\
1.154 \\
500 \\
- \\
\overline{935}\end{array}$ & $\begin{array}{l}3 \cdot 9 \\
3 \cdot 5 \\
5 \cdot 2 \\
4 \cdot 8 \\
5 \cdot 6 \\
4 \cdot 8 \\
3 \cdot 0 \\
6 \cdot 0 \\
6 \cdot 5\end{array}$ \\
\hline Mean & 841 & $4 \cdot 5$ & 9 & 828 & $4 \cdot 8$ \\
\hline
\end{tabular}




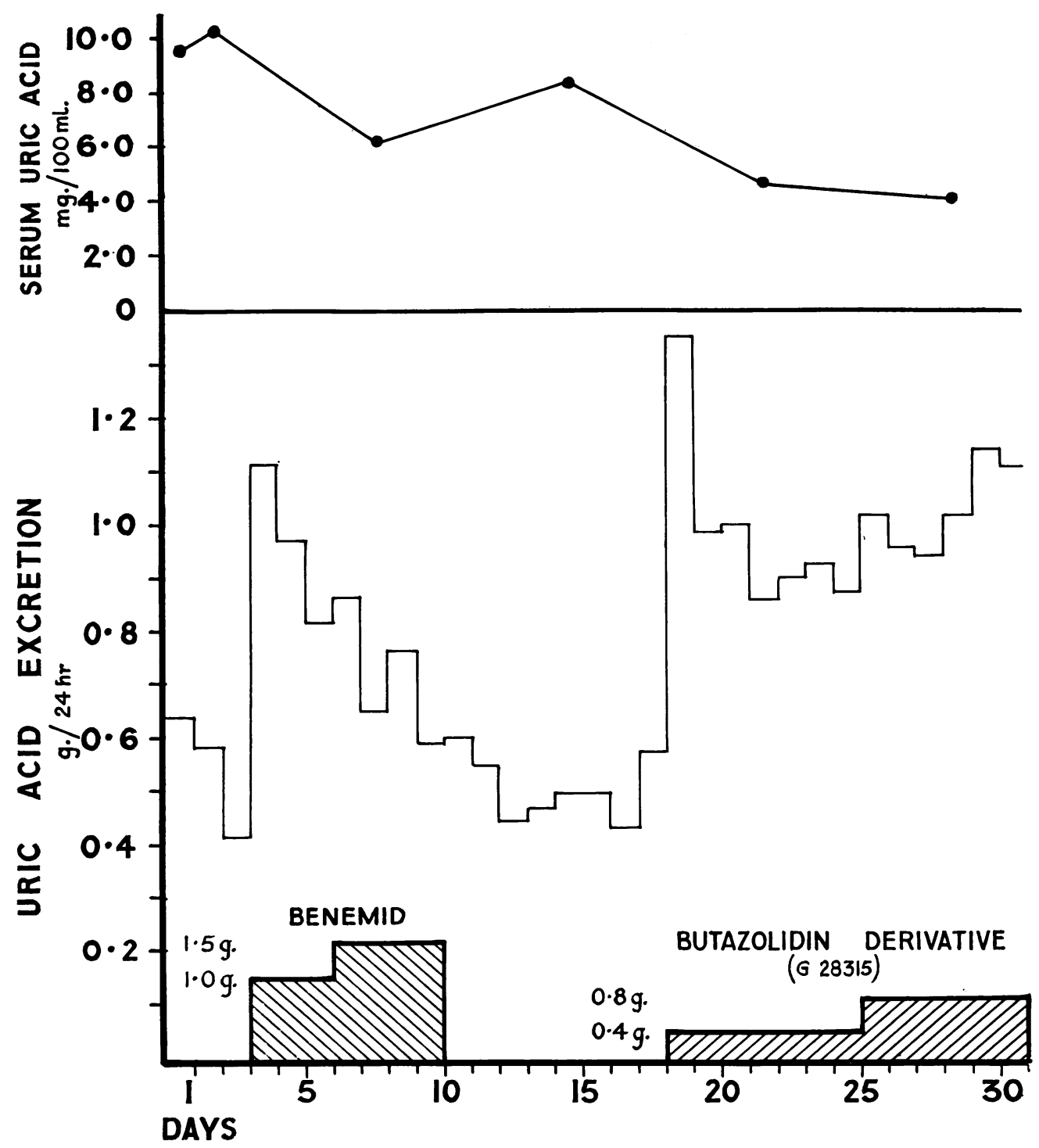

Fig. 2.-Patient 3, a man aged 44, with gout, showing response to Benemid and G.28 315.

progressive, and the percentage of granulocytes did not decrease.

Kersley and others (1951) and Gutman and Yü (1952) noticed that four out of eight cases treated with Benemid developed an acute attack of gout shortly after commencing the drug. Gutman (1957) found no tendency for G.25 671 or G.28 315 to provoke attacks, but Ogryzlo and Harrison (1957) remarked that six out of 25 cases receiving G.25 671 had acute episodes within the first 6 weeks. In the present series of cases treated with G.28 315, nine out of thirteen developed acute episodes within the first 6 weeks of treatment in spite of a maintenance dosage of colchicine. In one case it was the worst attack he had ever experienced and in the remainder the average interval between commencing treatment and the onset of an attack was shorter than the average intervals during the past 2 years. After this period of 6 weeks, however, attacks became less frequent and also less severe. 
In every case the episode was terminated rapidly by the use of phenylbutazone $600 \mathrm{mg}$. daily for 2 days, marked improvement being seen within 12 hours, even after colchicine had failed (Fig. 3). Even during this 6 weeks initial treatment several patients stated that chronic swelling was disappearing and one woman was able to wear her ring for the first time for 3 years.

Pascale, Dubin, and Hoffman (1952) found that in three cases $5 \mathrm{~g}$. salicylate held up the fall in plasma uric acid usually obtained with Benemid. Yü, Sirota, and Gutman (1953) found that in four cases receiving $1 \mathrm{~g}$. Benemid there was a slight depression of uric acid excretion on adding $600 \mathrm{mg}$. phenylbutazone during the first 2 days only, but the result of this addition was rather erratic. Ogryzlo and Harrison (1957) stated that salicylates had some blocking action on the uricosuria of G.25 671 and G.28 315, but that G.25 671 had no such effect on the excretion occasioned by Benemid.

As aspirin is so often given (or taken without permission) in gout, nine patients were stabilized on $400 \mathrm{mg}$. G.28 315 and $3 \cdot 5 \mathrm{~g}$. aspirin was given in addition. The fall in excretion of uric acid was startling; in eight it fell well below the control value and a similar sudden rise occurred in the serum uric

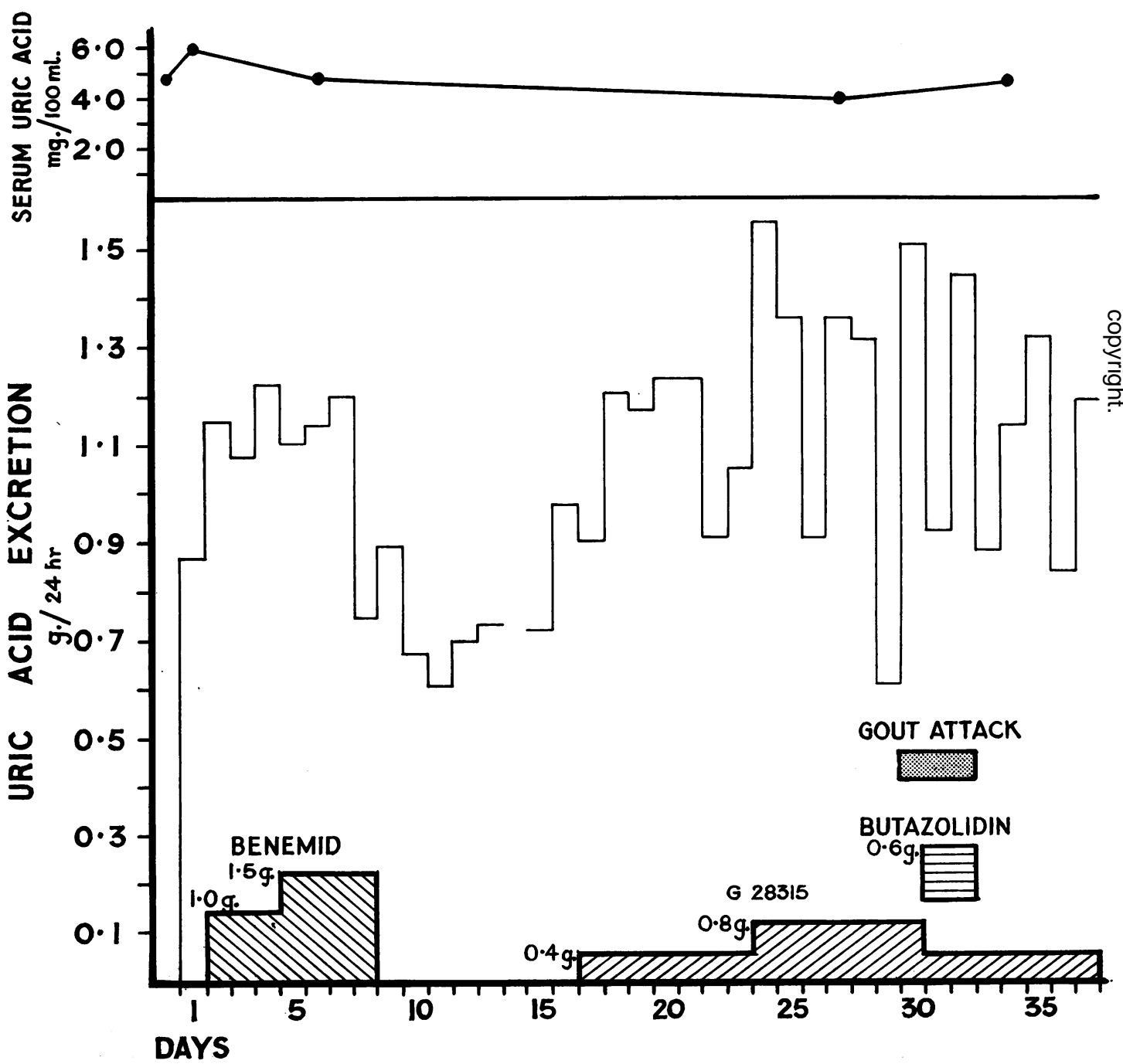

Fig. 3.-Patient 4, a man aged 41, with gout, showing response to Benemid and G.28 315, and added Butazolidin during an acute attack 
TABLE IV

INHIBITORY EFFECT OF ASPIRIN UPON URICOSURIA INDUCED BY G.28 315

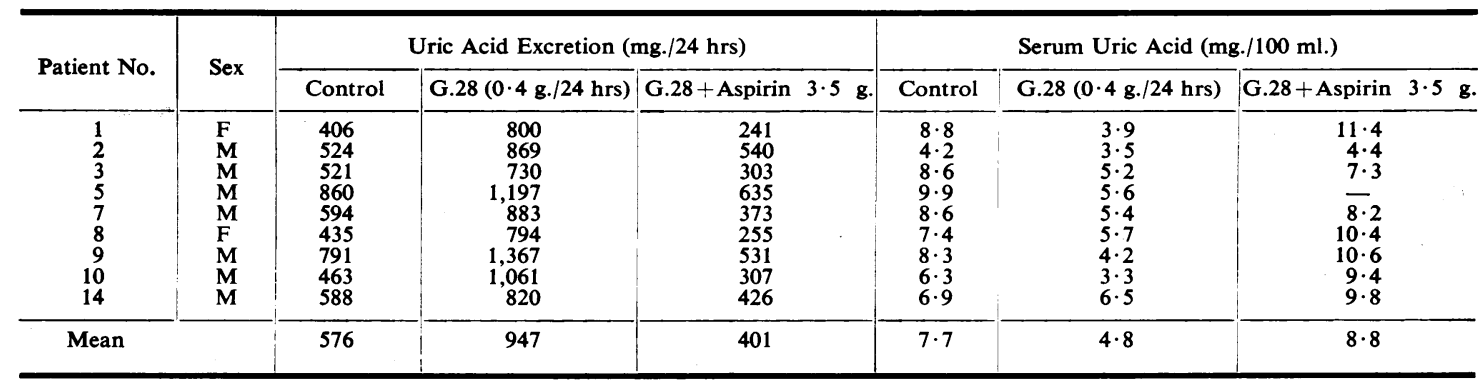

acid (Table IV). The mean values for daily excretion were control $576 \mathrm{mg}$., on G.28 $315947 \mathrm{mg}$. and on G.28 315 plus $3.5 \mathrm{~g}$. aspirin $401 \mathrm{mg}$. The corresponding serum uric acid means were $7 \cdot 7$, $4 \cdot 8$, and $8 \cdot 8 \mathrm{mg}$. per cent.

In two out of three cases given only $0.7 \mathrm{~g}$. aspirin together with G.28, the uric acid excretion fell to the control value, about a 25 per cent. decrease, but in the third patient there was no significant change. Three cases were given $120 \mathrm{mg}$. caffeine with their aspirin, and it was of interest to note that this increased the daily uric acid excretion by approximately $200 \mathrm{mg}$. Adding $3.5 \mathrm{~g}$. glycine to the aspirin had a very similar effect.

During the later stages of the trial, we were asked to compare the results obtained with $\mathrm{G} .28$ with those obtained with Longacid (p-carboxybenzalsulphodiethylamide), a drug of the Benemid type. Eleven patients were tested for a period of 1 to 12 weeks on this drug in a dosage of 1 to $2 \mathrm{~g}$. daily. All showed an increase in uric acid excretion and all but one a reduction in the plasma uric acid level, but in only three was the benefit comparable with that obtained with $400 \mathrm{mg}$. G.28. There were no toxic sequelae, but four patients complained, without questioning and for no apparent reason, of feeling very tired while taking the drug. All but one were pleased to return to G.28 medication.

In only two patients was renal function impaired, though two others had some transitory pain in the loins and red cells and crystals in the urine during the first 2 days of G.28 315 administration.

One patient aged 46 had a blood pressure of $230 / 120,1 \cdot 8 \mathrm{~g}$. albumin in the urine, but no red cells, and a blood urea of $60 \mathrm{mg}$. per cent. on admission. During treatment the blood pressure gradually dropped to $170 / 100$, the albumin decreased to $1 \cdot 1 \mathrm{~g}$., and the blood urea to $48 \mathrm{mg}$. per cent. In this patient the control average daily output of uric acid was $570 \mathrm{mg}$., and this rose to 800 on Benemid administration and to 1,000 on $400 \mathrm{mg}$. G.28 315 daily. The serum uric acid fell from $10 \cdot 3$ to $8 \cdot 6 \mathrm{mg}$. per cent. on Benemid and to $6.9 \mathrm{mg}$. per cent. on G.28 315 .

A second patient aged 52 had a blood pressure of $165 / 110,0.9 \mathrm{~g}$. albumin in the urine, and a blood urea of $45 \mathrm{mg}$. per cent. He developed a slight headache during the first few days of treatment but had no other untoward symptoms; the blood pressure tended to drop rather than rise and the urinary findings did not deteriorate. The control average daily output of uric acid was $550 \mathrm{mg}$. rising to 900 on Benemid and to 880 on $400 \mathrm{mg}$. G.28 315 daily. The serum uric acid fell from 7.8 to $6.5 \mathrm{mg}$. per cent. on Benemid and to $5 \mathrm{mg}$. per cent. on G.28 315 .

This suggests that, except when there is advanced renal failure, it is safe and useful to administer $1 \mathrm{~g}$. Benemid or $400 \mathrm{mg}$. G.28 315 daily, provided plenty of fluids are given, the urine is not acid, and the patient is carefully observed.

\section{Summary}

(1) In fifteen patients with typical gout the effect of G.28 315 on the clinical condition, uric acid excretion, and serum uric acid levels has been investigated.

(2) In two patients with abnormal renal function who are considered separately, the response was very satisfactory.

(3) In the remaining thirteen patients, the average daily excretion of uric acid rose from 551 to $880 \mathrm{mg}$. on a dosage of $400 \mathrm{mg}$. G.28 315 daily, and to $1,042 \mathrm{mg}$. in five cases on a dosage of $800 \mathrm{mg}$. G.28 315. The average serum uric acid fell from $7 \cdot 8$ to $4 \mathrm{mg}$. per cent.

(4) In five cases, the effect of $800 \mathrm{mg}$. G.28 315 was found to be significantly higher than that of 1 to $1.5 \mathrm{~g}$. Benemid, and the average drop in the serum uric acid level was greater (from $7 \cdot 8$ to $4 \mathrm{mg}$. instead of to $5 \cdot 2 \mathrm{mg}$. per cent.).

(5) Intermittent administration for 3 days per 
week did not maintain the low serum uric acid level.

(6) Continuous treatment for 3 to 8 months produced no toxic effects. There was an increased attack rate for the first 6 weeks and thereafter attacks became very infrequent and mild and regression of long-standing swelling was produced. Phenylbutazone terminated attacks at once in all cases.

(7) The addition of $3 \cdot 5 \mathrm{~g}$. aspirin to the G.28 315 medication completely reversed its effect, causing a fall in uric acid excretion below even the control value, and also a maximal rise in the serum uric acid level; an appreciable fall in uric acid excretion was noted in two of three patients on the addition of only $0.7 \mathrm{~g}$. aspirin.

(8) The results of the use of 1 to $2 \mathrm{~g}$. Longacid were compared in eleven cases. In all, there was an increased excretion of uric acid and in ten a drop in the plasma uric acid level; in only three, however, were the beneficial effects comparable with those obtained with $400 \mathrm{mg}$. G.28 315 .

It seems probable that G.28 315 may be of considerable therapeutic value in the interval treatment of gout, in a dosage of $400-800 \mathrm{mg}$. daily. It appears so far to be completely non-toxic and be more efficacious in lowering the serum uric acid level and increasing the uric acid excretion than the usually prescribed dosage of Benemid.

We should like to express our thanks to Dr. W. S. Stoddart of Geigy Pharmaceutical Company for co-operation and for the supply of the G.28 315 used in this clinical trial, and to Ward, Blenkinsop and Company Ltd. for the supply of Longacid.

\section{REFERENCES}

Bidmead, D S. (1951). J. clin. Path., 4, 370.

Burns, J. J., Yü, T. F., Ritterband, A., Perel, J. M., Gutman, A. B., and Brodie, B. B. (1957). J. Pharmacol., 119, 418.

Gutman, A. B., and Yü, T. F. (1952). Amer. J. Med., 13, 744.

Gutman, A. (1957). I ancet, $2,1258$.

Kersley, G. D., Mandel, L., and Bene, E. (1951). Ann. rheum. Dis., 10, 353 .

Ogryzlo, M. A., and Harrison, J. (1957). Jbid., 16, 425.

Pascale, L. R., Dubin, A., and Hoffman, W. S. (1952). J. Amer. med. Yii, Ass., 149, 1188.

Yü, T. F., Sirota, J. H., and Gutman, A. B. (1953). J. clin. Invest., 32, 1121 .

Valeur des agents uricosuriques et en particulier du G.28 315 dans la goutte

\section{RÉSUMÉ}

(1) On a étudié l'effet du G.28 315 sur l'état clinique, l'élimination d'acide urique et le taux sérique d'acide urique chez 15 malades atteints de goutte typique.

(2) Chez deux malades, dont la fonction rénale était anormale et qu'on considere pour cela séparement, la réponse était très satisfaisante.

(3) Chez les 13 autres malades, l'élimination moyenne par jour d'acide urique monta de 551 à $880 \mathrm{mg}$. avec une dose de $400 \mathrm{mg}$. de G.28 315 par jour, et dans 5 cas, une dose de $800 \mathrm{mg}$. éléva l'uricosurie à $1.042 \mathrm{mg}$. Le taux moyen d'acide urique sanguin tomba de $7,8 \mathrm{mg}$. à $4 \mathrm{mg}$. pour cent.

(4) Dans cinq cas l'effet de $800 \mathrm{mg}$. de G.28 315 fut

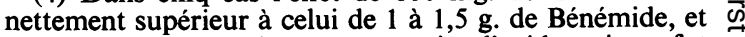
la chute moyenne du taux sanguin d'acide urique fut plus accentuée (de $7,8 \mathrm{mg}$. à $4 \mathrm{mg}$. au lieu de $5,2 \mathrm{mg}$. pour cent).

(5) Un traitement intermittent de 3 jours par semaine ne suffit pas pour maintenir le taux bas d'acide urique sanguin.

(6) Un traitement continu pendant 3 à 8 mois ne produisit pas d'effets toxiques. Le nombre d'attaques augmenta pendant les premières 6 semaines, après quoi ils devinrent bénins et peu fréquents et on observa une régression des tophus anciens. La phénylbutazone terminait toujours les attaques très rapidement.

(7) Quand on ajoutait 3,5 g. d'aspirine à la médication par le G.28 315, l'effet de celui-ci était renversé: l'uricosurie tombait en dessous du chiffre de contrôle et l'uricémie montait à son maximum. Chez deux sur trois malades on obtint une chute appréciable de l'uricosurie avec $0,7 \mathrm{~g}$. seulement d'aspirine.

(8) Chez 11 malades on compara les résultats obtenus avec l'emploi de 1 à 2 g. de Longacid. Chez tous l'uricosurie augmenta et chez dix l'uricémie diminua, mais chez trois seulement l'effet favorable du Longacid fut comparable à celui de $400 \mathrm{mg}$. de G.28 315 .

Il semble que la valeur du G.28 315 dans le traitement de la goutte entre les attaques, en doses de 400 à $800 \mathrm{mg}$ par jour, est considérable. Autant qu'on sache, il eso tout à fait atoxique et plus efficace que le Bénémide ex doses habituelles pour faire diminuer le taux sériquê d'acide urique et augmenter son excrétion urinaire.

Valor de los agentes uricosúricos y en particular del G.28 315 en la gota

\section{Sumario}

(1) Se estudió el efecto del G.28 315 sobre el estado clínico, la eliminación de ácido úrico y la tasa sérica de ácido úrico en quince enfermos con gota típica.

(2) En dos enfermos, considerados separadamente por acusar la función renal anormal, la respuesta fué muy satisfactoria.

(3) En los demás trece enfermos, la eliminación diaria media de ácido úrico subió de 551 a $880 \mathrm{mg}$. con una dosis diaria de $400 \mathrm{mg}$. de G.28 315 y, en cinco casos, una dosis de $800 \mathrm{mg}$. hizo subir la uricosuria a $1.042 \mathrm{mg}$. El ácido úrico sérico bajó de $7,8 \mathrm{mg}$. a $4 \mathrm{mg}$. por ciento.

(4) En cinco casos el efecto de $800 \mathrm{mg}$. de G.28 315 fué netamente superior al efecto de 1 a 1,5 gramos de Benemid y la baja de la uricemia fué más acusada (de 7,8 a $4 \mathrm{mg}$. en vez de 5,2 mg. por ciento).

(5) Un tratamiento intermitente de 3 dias por semana no basta para mantener una cifra baja de ácido úrico en el suero.

(6) Un tratamiento contínuo de 3 a 8 meses no produjo efectos tóxicos. El número de ataques aumentó durante las primeras 6 semanas, pero luego estos ataques se volvieron poco frecuentes y benignos y una regresión de tofos antiguos fué observada. La fenilbutazona siempre cortaba los ataques.

(7) $\mathrm{Al}$ añadir 3,5 g. de aspirina a la medicación con el 
G.28 315, se obtenía un efecto inverso: la uricosuria caía debajo la cifra de control y la uricemia alcanzaba lo máximo. En dos de tres enfermos hubo una baja apreciable de la uricosuria con sólo $0,7 \mathrm{~g}$. de aspirina.

(8) En 11 enfermos se compararon los resultados obtenidos con 1 a 2 g. de Longacid. La uricosuria aumentó en todos y la uricemia disminuyó en diez casos, pero en tres casos solamente el efecto favorable de
Longacid se pudo comparar al obtenido con $400 \mathrm{mg}$. de G.28 315 .

El valor del G.28 315 en el tratamiento de la gota entre los ataques, en dosis diarias de 400 a $800 \mathrm{mg}$., parece considerable. A lo que se sabe, este producto es enteramente atóxico y más eficaz que el Benemid en dosis habituales para hacer bajar la uricemia y subir la uricosuria. 